MANTHAN: Journal of Commerce and Management Volume 4, Issue 1, January-June 2017, pp. 1-17 doi: 10.17492/manthan.v4i01.9604

\title{
Satisfaction or Motivation-What precedes Performance? A Study of Sales Force in the Life Insurance Industry
}

\author{
Saroj Kumar Sahoo* and Sandhyarani Sahoo**
}

\begin{abstract}
While there is considerable research on employees' satisfaction, motivation and performance, there is lack of conclusive evidence on these dimensions of organisational betterment. This puzzle becomes more complex for sales-force that deals with great stress in Indian life insurance context. This paper explores the underlying factors of satisfaction and motivation separately and predicts the impact of satisfaction on motivation, and the impact of motivation on performance. To justify these objectives empirically, a structured questionnaire has been executed to life-insurance sales-force with a sample size of 345 through stratified random sampling method. The data is analysed through explorative factor analysis, which is followed by regression analysis to test the prediction of motivation by satisfaction and then prediction of performance by motivation. The findings reveal that there is significant positive impact of sales-force satisfaction on their motivation, which ultimately has a significant positive impact on performance of sales-force in the life-insurance industry.
\end{abstract}

Keywords: Sales-force; Satisfaction; Motivation; Performance; Life-insurance industry: regression, factor analysis.

\subsection{Introduction}

Research in the life-insurance selling in India is very crucial and meaningful both for the industry and academics, because selling life-insurance is not easy, especially to the low-income and middle class clients. The target customers' low awareness on the financial products, risk estimation capability and young sellers having no previous insurance selling experience or have other responsibilities in addition to selling insurance makes the life-insurance selling very much stressful in India.

*Corresponding author; Assistant Professor, PG. Dept. of Business Administration, Sambalpur University, Sambalpur, Odisha, India. (Email id: sahoosaroj78@yahoo.com)

**Assistant Manager, ICICI Bank, Budharaja, Sambalpur, Odisha, India.

(Email id: sahoosandhya15@gmail.com) 
This problem is compounding as vulnerability of Indian target customers' towards negative word-of-mouth in the target market. Further, any improper selling that leads to customers' dissatisfaction can be a root for reputational risks of concerned organisation, which make the sales-force not only response but also highly accountable for most of the aspects of the life-insurance companies and their job becomes stressful. Thus, there is always a question of that how the life-insurance sales employees will be motivated or satisfied to perform better. These discussions are substantiated by the results of some studies/surveys which show that $60 \%$ of the insurance sales force leaves the company in less than one year and $20 \%$ of the employees who contribute to $80 \%$ of the productivity (Pathak and Tripathi, 2010). Inequity of compensation even at same level, working extra time to fulfill the target and dissatisfaction on overall income of lifeinsurance sales-force (Verma and Aggarwal, 2012) are causing the job even stressful, which refers the importance of managing the life-insurance sales employees through the variables of satisfaction and motivation. The current study is more relevant in this regard as number of individual agents has increased $(1,15,709$ to 2188500$)$ to nearly 20 times the number from the year 2001 to 2014; there are 689 Corporate Agents working for life insurance industry by 31st March 2014, life insurance industry recorded a premium income of Rs.3,14,283 crore during 2013-14 including renewal premium as well as new premium and the number of new individual policies issued in 2013-14 stood at 4.08 crore (according to IRDA annual reports). Even with the above encouraging data, there is a great concern regarding life insurance sales employees' in India looking at their personal professional life. This discussion addresses a linkage between satisfaction, motivation and performance of the above said sales force.

\subsection{Research problem}

Both the worlds of academics and industry have seen great research findings relating to motivation, satisfaction and performance of employees. Few of them addressed these three dimensions on the sales employees, especially in life insurance industry. In this industry, organizational performance mostly depends on the sales force, which is more complex in Indian scenario. Further most of the researchers and theorists analysed 'motivation' and 'satisfaction' separately as the predictors of performance or analysed in an industry other than a typical service industry like life-insurance. Hence the current study putting the research problem as "what exact sequence of satisfaction and motivation precedes the sales-force performance"? The underlying objectives for studying this research problem are stated below. 


\subsection{Objectives of the study}

The major objectives of the study are as follows:

(i) To identify the underlying factors of sales-force motivation and satisfaction in life insurance industry;

(ii) To examine predictability of motivation factors for performance of sales force;

(iii) To examine the impact of satisfaction factors on individual motivating factors;

(iv) To explore a sequential relationship satisfaction, motivation and performance of sales-force in life insurance in India.

\subsection{Literature Review}

\subsection{Relation between satisfaction, motivation and performance}

There is no evidence to support the conclusion that sales persons' job satisfaction is directly related to job performance as measured in annual sales, while replicating the research done by Bagozzi in 1978 (Hafer and McCuen,1985). Further Hafer and McCuen (1985) referred that sales performance has negligible and negative correlation with job satisfaction. While examining the relationships among lone wolf tendencies, sales force performance, job satisfaction, and turnover intentions with pharmaceutical salespeople (Mulki et. al, 2007) revealed that lone wolf tendencies lead to a lower contextual performance as represented by the dimensions of helping, courtesy, and sportsmanship. Again the said researchers found out that task performance is subsequently reduced, and hence turnover intentions are higher based on lower job satisfaction of salespeople with lone wolf tendencies. There is a negative correlation between positive achievement motivation behaviour (PAMB) and salespersons extrinsic motivation. PAMB has produced a significant influence in salespersons intrinsic motivation and performance. Salespersons believe that to the extent their supervisors exercise achievement motivation behaviour, the greater likelihood that intrinsic rewards would be generated for greater performance. Also it has been seen that as compared to extrinsic motivation, intrinsic motivation is shown to produce relatively a greater impact on performance. Further it is shown that the Coefficients of correlations and other descriptive statistics for all variables refers that relationships between positive achievement motivation behaviour (PAMB), intrinsic motivation and performance has a significant positive relationship (Choudhury M. S., 2007).

While doing a research on motivation management capabilities through selfregulatory training of salespeople and the impact of motivation management capabilities on performance, Leach, Liu and Johnson (2007) found that salesperson's level of motivation control was related to salesperson's performance. However motivation 
4 | MANTHAN: Journal of Commerce and Management, Volume 4, Issue 1, Jan-Jun 2017

control was not found to be related to performance in lower selling-knowledge group sales people and in high selling knowledge group. It is also found that self-regulation training was found to be positively related to a salesperson's emotional control and motivation control and negatively related to role ambiguity. The study of Nohria et. al (2008) is very relevant to the current research problem that four emotional drives like 'acquire', 'bond', 'comprehend' and 'defend' are responsible for employees motivation. Corresponding to these drives, the four leavers that they proposed were 'reward system', 'culture', 'job design' and 'performance management \& resource allocation process' respectively.

\subsection{Relation between satisfaction, motivation and performance in insurance industry}

Positive attributional style (CoPos) seems to be the more important ingredient in achievement and motivation and positive attributional style (CoPos) was positively correlated with sales, showing that salespeople scoring higher in CoPos were more successful than their lower scoring colleagues. So, positive attributional style for achievement-related situations was the best predictor of performance ranking (Corr and Gray, 1996). Positive moods of insurance sales agent predicted task performance indirectly through both interpersonal (helping other co-workers and their support) and motivational (self-efficacy and task persistence) processes (Tsai et al., 2007). Insurance sales force in India leave an organisation if they are not satisfied with the job related factors like stress, career advancement and the environment. Sales force satisfaction depends upon multiple levels of needs simultaneously and aspires for a job which offers a good mix of primary, social and esteems needs like fair compensation and employment, job security, ease of working in flexible timing, and career advancement (Pathak and Tripathi, 2010).

The job situation is influencing the motivation of insurance officials to a reasonable extent, for which the job situation is judged on the basis of three factors like pattern of working, chance to learn and use of abilities (Balachandar et. al, 2010). Further the mean values of the above said three motivational factors are almost similar for both the private and government owned insurance company officers. It was also investigated that work motivation (including willingness to work, job satisfaction, and organizational commitment) is an efficient predictor of work related behaviours like absenteeism, number of hours worked, and intention to quit. In this connection, another study refers that by all means, rewards are part of the business plan to attract, retain and motivate the agents to achieve success in their life, as well as contributing in meeting the company's objective (San et al., 2012). In their working-paper, Anagol et. al (2013) said 
that Indian insurance agents (commissions-motivated agents) generally recommend alternative products with high commissions but no disclosure requirement. The above literatures provoke the current researchers to clarify the relationship between satisfaction, motivation \& performance of the sales employees in life-insurance industry in India.

\subsection{Research Design and Methodology}

\subsection{Sample design}

Causative research design is followed by this research work, where the cause and effect relationships have been justified between satisfaction and motivation as independent variable and performance as dependent variable. With the stratified sampling, the sample size is 345 and the sample elements refers to any life-insurance sales people like independent agents, private banks sales employees, bank-assurance employees. The initially planned sample size was 500 intended to cover five major geographical areas of Odisha, India, where insurance sales employees would be more concentrated in number. However, because of the unwillingness of the respondents to provide data, time and budgetary constraints, the sample size was restricted to 345 . A structured questionnaire for respondent survey is designed, which was pre-tested before finalising. Self-administered questionnaires were distributed to the life insurance sales personnel/agents to get the qualitative data about their perception and attitude towards different dimensions of motivation and satisfaction. Five point Likert scale was used in the questionnaire. All the data were collected from respondents through personal contact approach.

\subsection{Respondents' profile in the sample}

The demographic profile of the sample respondents (life insurance sales force) has six parameters and is presented to understand the respondents, i.e., gender, age, marital status, education, experience in insurance industry, and income. $89.9 \%$ are the male respondents \& $10.1 \%$ refers to female respondents. 59.7 percent are young respondents whose ages are all below 35 years, $4.1 \%$ coming under older respondents whose ages are above 49 , and $36.3 \%$ respondents belongs to middle age group. Out of all the respondents, $67.8 \%$ are married and $32.2 \%$ are unmarried. It is observed that most of the respondents $(62.9 \%)$ are under-graduates, $27 \%$ are post-graduates and $10.1 \%$ carry the professional educational qualification. So far as experience is concerned, $47.2 \%$ of the respondents has less than 5 years of experience in insurance industry as the sales employee, $44.1 \%$ has the experience between 6 years to 15 years 
6 | MANTHAN: Journal of Commerce and Management, Volume 4, Issue 1, Jan-Jun 2017

and rest $8.7 \%$ has more than 15 years of experience. Looking at the annual income of the respondents, $69.9 \%$ comes under Rs. 3.00 lakh, $18.5 \%$ fall in between 3 lakh to 5 lakhs \& $11.6 \%$ of the respondents have more than 5 lakhs of annual income.

\subsection{Results and Discussion}

A fair way to start any empirical analysis is the reliability test (by Cronach's $\alpha$ ) of the scale used in the questionnaire. In the current study explorative factor analysis is executed separately for the set of questions intended for direct measurement of motivation, indirect measurement of motivation variables and for the satisfaction of lifeinsurance sales-force. The factors of motivation as regressors (independent) are put for linear regression analysis with selling performance as regressand (dependent variables) to know the impact of motivating factors on selling performance and then the factors of satisfaction are put to linear regression with motivation factors (as dependent variables) to know the impact of satisfaction on motivation.

\subsection{Scale reliability}

The scale reliability of the questionnaire is nearly $93 \%$ as the reliability statistics for Cronbach's Alpha is 0.932, as is evident from Table 1.

\section{Table 1: Test of Reliability}

\begin{tabular}{|c|c|c|c|c|c|c|c|c|c|}
\hline \multicolumn{4}{|c|}{ Case Processing Summary } & \multicolumn{4}{|c|}{ Scale Statistics } & \multicolumn{2}{|c|}{ Reliability Statistics } \\
\hline & & $\mathrm{N}$ & $\%$ & Mean & Variance & $\begin{array}{l}\text { Std. } \\
\text { Deviation }\end{array}$ & $\begin{array}{l}\text { No. } \\
\text { Items }\end{array}$ & $\begin{array}{l}\text { Cronbach's } \\
\text { Alpha }\end{array}$ & $\begin{array}{l}\text { No. of } \\
\text { Items }\end{array}$ \\
\hline \multirow[t]{3}{*}{ Case } & Valid & 344 & 99.7 & 296.69 & 1320.273 & 36.336 & 81 & 0.932 & 81 \\
\hline & Excluded $^{\mathrm{a}}$ & 01 & 0.3 & & & & & & \\
\hline & Total & 345 & 100 & & & & & & \\
\hline
\end{tabular}

\subsection{Factor analysis}

To extract the factors from the items which indirectly explain the sales force motivation, 32 items were factor analysed using principal component analysis and Varimax rotation. With Kaiser Normalization, it was found that the sample adequacy is $88 \%(\mathrm{KMO}=0.885)$ and this is significant $(\mathrm{Sig}=0.000)$. From 32 variables, 9 factors have been extracted, which explain $60 \%$ (cumulative $\%=60.060$ ) variance. So these nine factors were assigned with the name as 'belongingness', 'internal environment', 
'ease of completing the work', 'scope of development', 'rationalization', 'personal development', 'open-ness', 'no-presser feeling', \& 'freedom' referring to the rotated component matrix (Table 2).

Table 2: Rotated Component Matrix

\begin{tabular}{|c|c|c|c|c|c|c|c|c|c|}
\hline & \multicolumn{9}{|c|}{ Component } \\
\hline & 1 & 2 & 3 & 4 & 5 & 6 & 7 & 8 & 9 \\
\hline Sales rep. proud of their own company. & .663 & & & .269 & & & & & \\
\hline Sales rep. feel valued own company. & .620 & .205 & & & & & .221 & & \\
\hline $\begin{array}{l}\text { Sales rep. able to see their own future in } \\
\text { the present company. }\end{array}$ & .618 & & & .265 & .274 & .258 & & & \\
\hline $\begin{array}{l}\text { Sales rep. proud of being part of } \\
\text { department in the present company. }\end{array}$ & .601 & .533 & & & & & & & \\
\hline $\begin{array}{l}\text { Clear \& effective appraisal system for } \\
\text { career development in the present } \\
\text { company. }\end{array}$ & .454 & & .303 & & & & & .444 & \\
\hline $\begin{array}{l}\text { Sales rep. knows that there is no secrecy } \\
\text { in the team of present company. }\end{array}$ & & .739 & & & & & .258 & & \\
\hline $\begin{array}{l}\text { Sales rep. can share necessary } \\
\text { information freely within team of } \\
\text { present company. }\end{array}$ & & .703 & .372 & & & & & & \\
\hline $\begin{array}{l}\text { Sales rep. really respects their boss in } \\
\text { the present company. }\end{array}$ & .352 & .518 & & & .208 & & & & .354 \\
\hline $\begin{array}{l}\text { Sales rep. need not to compete unfairly } \\
\text { present company. }\end{array}$ & & .515 & & .263 & & .384 & & & \\
\hline $\begin{array}{l}\text { Sales rep. knows that there is a } \\
\text { rationalization of cost in their present } \\
\text { company. }\end{array}$ & .217 & & .643 & & & & .285 & & \\
\hline $\begin{array}{l}\text { Sales rep. can access any information } \\
\text { for their appropriate job done in their } \\
\text { present company. }\end{array}$ & & & .610 & & & & .210 & & .282 \\
\hline $\begin{array}{l}\text { Sales rep. know that their job is } \\
\text { understood by every one of the } \\
\text { company. }\end{array}$ & .358 & .220 & .566 & & & & & & \\
\hline $\begin{array}{l}\text { Sales rep. can refer their authorities for } \\
\text { their unclear work in the present } \\
\text { company. }\end{array}$ & & & .536 & .319 & .249 & & & & .259 \\
\hline $\begin{array}{l}\text { Sales rep. realizes that the meetings are } \\
\text { out come oriented in present company. }\end{array}$ & & & & .616 & & & & & \\
\hline $\begin{array}{l}\text { Employees are not constrained by many } \\
\text { unnecessary rules. }\end{array}$ & & & & .575 & & .265 & .460 & & \\
\hline
\end{tabular}




\begin{tabular}{|c|c|c|c|c|c|c|c|c|c|}
\hline $\begin{array}{l}\text { Employees are told that they are } \\
\text { progressing in their work. }\end{array}$ & .375 & & & .566 & & & & .304 & \\
\hline $\begin{array}{l}\text { Employees' selling performance is } \\
\text { better than other company's sales } \\
\text { employees. }\end{array}$ & .354 & & & .563 & & & & & \\
\hline $\begin{array}{l}\text { Sales rep knows that majority of their } \\
\text { time spent with valuable work in present } \\
\text { company. }\end{array}$ & & & & & .754 & & & & \\
\hline $\begin{array}{l}\text { Sales rep. finishes their work at a } \\
\text { reasonable time in the present company. }\end{array}$ & .229 & & & & .690 & & & & \\
\hline $\begin{array}{l}\text { Sales rep. realizes that their work suits } \\
\text { to the physical environment of the } \\
\text { present company. }\end{array}$ & & .274 & .227 & .254 & .532 & & & & \\
\hline $\begin{array}{l}\text { Sales rep. can express the core value of } \\
\text { their companies. }\end{array}$ & .245 & & & & & .667 & .208 & & \\
\hline $\begin{array}{l}\text { Employees' job consists of various } \\
\text { work. }\end{array}$ & & & .493 & & & .525 & & & \\
\hline $\begin{array}{l}\text { Sales rep. knows the unique selling } \\
\text { point of present company. }\end{array}$ & .260 & .306 & .341 & & & .522 & & .225 & \\
\hline $\begin{array}{l}\text { Employees get appropriate leave for } \\
\text { personal work. }\end{array}$ & & .228 & & .316 & & .512 & & & .260 \\
\hline $\begin{array}{l}\text { Sales rep. not afraid-off to make mistake } \\
\text { in their present company. }\end{array}$ & & & & & & & .677 & & \\
\hline $\begin{array}{l}\text { Sales rep. realizes that their feeling are } \\
\text { asked \& listened in present company. }\end{array}$ & & & .269 & & & & .627 & .307 & \\
\hline $\begin{array}{l}\text { Sales rep can give constructive critics in } \\
\text { their companies. }\end{array}$ & & & & & & & .487 & & .459 \\
\hline $\begin{array}{l}\text { Sales rep. knows that there are } \\
\text { opportunities to develop in present } \\
\text { company. }\end{array}$ & & & .285 & & & & & .631 & \\
\hline $\begin{array}{l}\text { Sales rep. knows that poor performance } \\
\text { is not tolerated in the present company. }\end{array}$ & & .218 & & .217 & .383 & .290 & & .579 & \\
\hline $\begin{array}{l}\text { Sales rep. is not threatened by their team } \\
\text { mates in the present company. }\end{array}$ & & .495 & & & & & & .495 & \\
\hline $\begin{array}{l}\text { Sales rep. realizes that their success is } \\
\text { acknowledged publicly in present } \\
\text { company. }\end{array}$ & & & & .235 & & & & & .686 \\
\hline $\begin{array}{l}\text { Sales rep. can express openly their } \\
\text { future \& ambition in present company. }\end{array}$ & .284 & & & & .203 & .254 & & & .605 \\
\hline
\end{tabular}


To extract the factors from the items which directly explain the sales force motivation, 16 items were factor analysed using Principal Component Analysis and Varimax rotation. With Kaiser Normalization, it found that the sample adequacy is $83 \%$ $(\mathrm{KMO}=0.830)$ and this is significant $(\mathrm{Sig}=0.000)$. From 16 variables, 5 factors have been extracted, which explain $60 \%$ (cumulative $\%=60.060$ ) variance. These five factors can be named as 'intangible returns', 'tangible returns', 'recognition', 'secured future' and 'scope of more earning' referring to the below mentioned rotated component matrix (Table 3).

Table 3: Rotated Component Matrix

\begin{tabular}{|c|c|c|c|c|c|}
\hline & \multicolumn{5}{|c|}{ Component } \\
\hline & 1 & 2 & 3 & 4 & 5 \\
\hline $\begin{array}{l}\text { Cards given on special occasions do motivates the insurance } \\
\text { sales-force. }\end{array}$ & .649 & .374 & & .231 & \\
\hline $\begin{array}{l}\text { Official birth day celebration do motivate the insurance sales- } \\
\text { force. }\end{array}$ & .628 & .481 & & & \\
\hline $\begin{array}{l}\text { Gift and bonus on special occasions do motivates the insurance } \\
\text { sales-force. }\end{array}$ & .625 & .232 & .280 & & .216 \\
\hline Sales contest among employees motivates them. & .585 & & .256 & & \\
\hline Pleasure trip/cocktail party motivates the insurance sales-force. & .459 & .243 & .308 & .414 & \\
\hline $\begin{array}{l}\text { Group-wise incentive motivates the pharmaceutical sales- } \\
\text { force. }\end{array}$ & & .693 & .317 & & .220 \\
\hline Zone-wise incentive motivates the insurance sales-force. & .265 & .684 & & & \\
\hline Invitation to lunch by top executive motivates employees. & & .629 & & .260 & \\
\hline $\begin{array}{l}\text { Reward and recognition like star award, trophies, promotion } \\
\text { motivates. }\end{array}$ & .201 & & .761 & & \\
\hline Product-wise incentive motivates the life-insurance sales-force. & & .277 & .680 & & \\
\hline Regular training on various product motivates employees. & & .314 & .560 & & \\
\hline Pension benefits for employees' old age motivate them. & & & & .801 & \\
\hline Benefits for family members motivate employees. & .233 & & .227 & .773 & \\
\hline $\begin{array}{l}\text { Extra effort leads to improve performance in present } \\
\text { organization. }\end{array}$ & & & & & .796 \\
\hline Improved performance linked always to increased reward & & & .302 & & .749 \\
\hline $\begin{array}{l}\text { Ratio of highest paid sales person to average paid sales person } \\
\text { in high. }\end{array}$ & .447 & & & .372 & .513 \\
\hline
\end{tabular}


For extracting 'factors' from the items which explain the sales force satisfaction, 15 items were factor analysed using principal component analysis and Varimax rotation. With Kaiser Normalization, it found that the sample adequacy is $81 \%(\mathrm{KMO}=0.810)$ and this is significant $(\mathrm{Sig}=0.000)$. From 15 variables, 5 factors have been extracted, which explain $61 \%$ (cumulative $\%=61.549$ ) variance. These five factors can be named as 'career planning', 'work condition', 'assignments', 'relationships' and 'compensation' referring to the below mentioned rotated component matrix (Table 4).

Table 4: Rotated Component Matrix

\begin{tabular}{|c|c|c|c|c|c|}
\hline & \multicolumn{5}{|c|}{ Component } \\
\hline & 1 & 2 & 3 & 4 & 5 \\
\hline $\begin{array}{l}\text { Level of satisfaction on structured appraisal system of present } \\
\text { company. }\end{array}$ & .737 & .272 & .245 & & \\
\hline $\begin{array}{l}\text { Level of satisfaction on structured mentoring system of present } \\
\text { company. }\end{array}$ & .685 & .203 & .288 & & \\
\hline $\begin{array}{l}\text { Level of satisfaction on structured succession planning of } \\
\text { present company. }\end{array}$ & .611 & .368 & & & \\
\hline $\begin{array}{l}\text { Level of satisfaction on additional responsibilities given by the } \\
\text { company. }\end{array}$ & .550 & & & .296 & \\
\hline $\begin{array}{l}\text { Level of satisfaction on autonomy on present role of present } \\
\text { company. }\end{array}$ & & .739 & & .281 & \\
\hline $\begin{array}{l}\text { Level of satisfaction on recognition for results of present } \\
\text { company. }\end{array}$ & .328 & .682 & & & \\
\hline Level of satisfaction on job security of present company. & & .529 & .424 & .256 & .317 \\
\hline Level of satisfaction on current product of present company. & .246 & & .766 & & \\
\hline $\begin{array}{l}\text { Level of satisfaction on current product pipeline of present } \\
\text { company. }\end{array}$ & & & .731 & .338 & \\
\hline Level of satisfaction on company culture of present company. & & .504 & .529 & & \\
\hline $\begin{array}{l}\text { Level of satisfaction on relationship with manager of present } \\
\text { company. }\end{array}$ & & .259 & & .715 & \\
\hline $\begin{array}{l}\text { Level of satisfaction on regularity of training of present } \\
\text { company. }\end{array}$ & .242 & & & .709 & \\
\hline $\begin{array}{l}\text { Level of satisfaction on current bonus scheme of present } \\
\text { company. }\end{array}$ & & & .216 & & .766 \\
\hline $\begin{array}{l}\text { Level of satisfaction on current share scheme of present } \\
\text { company. }\end{array}$ & .205 & & & & .756 \\
\hline Level of satisfaction on current salary of present company. & & & .242 & .458 & .467 \\
\hline
\end{tabular}




\subsection{Impact of sales force motivation on performance}

The results of ANOVA report a significant ( $\mathrm{Sig}=0.000$, less than 0.05) Fstatistic, indicating that using the model is better than guessing the mean. As a whole, the regression model is explaining nearly $13 \%$ of the variation in sales-force performance (Table 5). Two predictors like 'belongingness' and 'internal environment' contribute to the model more because of the significant ( $\mathrm{Sig}=0.001$ and 0.013$)$ beta value $(0.223$ and 0.134 respectively), which is evident from Table 6. Surprisingly two motivating factors such as 'ease of completing work' and 'scope of development' have significant (0.016 and 0.000 ) negative relationship with sales-force performance of the life-insurance industry in India as referred from the 'beta values' ( -0.130 and -0.200 respectively) in Table 6. From directly measured motivating factors, only the factor 'secured future' has significant $(0.36)$ impact (beta value $=2.105$ ) on sales force performance. The rest of the nine factors do not show any significant impact on performance of the life insurance sales people.

In the regression model (Table 6), very less multicollinearity is observed as the lowest tolerance value is 0.581 and most of other tolerance values are nearly 0.9 (When the tolerances are close to 0 , there is high multicollinearity) and the highest VIF value is 1.720. A variance inflation factor greater than 2 is usually considered problematic and therefore the present VIF justifies very less multicollinearity as can be referred from Table 6.

Table 5: Regression Statistics

\begin{tabular}{|c|c|c|c|c|c|c|c|c|c|}
\hline \multicolumn{6}{|c|}{ Model Summary } & \multicolumn{4}{|c|}{ Model fitting by ANOVA } \\
\hline \multirow[t]{2}{*}{ Model } & \multirow[t]{2}{*}{$\mathrm{R}$} & \multirow{2}{*}{$\begin{array}{c}\mathrm{R} \\
\text { Square }\end{array}$} & \multirow{2}{*}{$\begin{array}{l}\text { Adjusted } \\
\text { R Square }\end{array}$} & \multirow{2}{*}{$\begin{array}{l}\text { Std. Error } \\
\text { of the } \\
\text { Estimate }\end{array}$} & $\begin{array}{l}\text { Change } \\
\text { statistics }\end{array}$ & & $\begin{array}{l}\text { Sum of } \\
\text { squares }\end{array}$ & $\mathrm{F}$ & Sig. \\
\hline & & & & & $\begin{array}{c}\text { Sig. F } \\
\text { Change }\end{array}$ & Regression & 55.016 & \multirow[t]{3}{*}{4.664} & \multirow[t]{3}{*}{$0.000^{\mathrm{a}}$} \\
\hline \multirow[b]{2}{*}{1} & \multirow[b]{2}{*}{$0.406^{\mathrm{a}}$} & \multirow[b]{2}{*}{0.165} & \multirow[b]{2}{*}{0.130} & \multirow[b]{2}{*}{0.918} & \multirow[b]{2}{*}{0.000} & Residual & 278.016 & & \\
\hline & & & & & & Total & 333.032 & & \\
\hline \multicolumn{10}{|c|}{$\begin{array}{l}\text { a. Predictors: (Constant), belongingness, internal environment, ease of completing the work, scope of } \\
\text { development, rationalization, personal development, openness, no-presurer feeling, freedom, intangible } \\
\text { returns, tangible returns, recognition, secured future and scope of more earning. } \\
\begin{array}{l}\text { Dependent Variable: Sales-force performance in own company and } d f-1 \text { and df-2 refer to } 14 \& 330 \\
\text { respectively. }\end{array}\end{array}$} \\
\hline
\end{tabular}


12 | MANTHAN: Journal of Commerce and Management, Volume 4, Issue 1, Jan-Jun 2017

Table 6: Coefficients

\begin{tabular}{|c|c|c|c|c|c|c|c|c|c|}
\hline \multirow{2}{*}{\multicolumn{2}{|c|}{ Model }} & \multirow{2}{*}{\begin{tabular}{|c|}
$\begin{array}{c}\text { Standardized } \\
\text { Coefficients }\end{array}$ \\
Beta \\
\end{tabular}} & \multirow[t]{2}{*}{$\mathbf{t}$} & \multirow[t]{2}{*}{ Sig. } & \multicolumn{3}{|c|}{ Correlations } & \multicolumn{2}{|c|}{$\begin{array}{c}\text { Collinearity } \\
\text { Statistics }\end{array}$} \\
\hline & & & & & $\begin{array}{l}\text { Zero- } \\
\text { order }\end{array}$ & Partial & Part & $\begin{array}{c}\text { Tolera- } \\
\text { nce }\end{array}$ & VIF \\
\hline & (Constant) & & 72.030 & .000 & & & & & \\
\hline & Belongingness & .223 & 3.377 & .001 & .176 & .183 & .170 & .581 & 1.720 \\
\hline & $\begin{array}{l}\text { Internal } \\
\text { environment }\end{array}$ & .134 & 2.489 & .013 & .153 & .136 & .125 & .876 & 1.141 \\
\hline & $\begin{array}{l}\text { Ease of } \\
\text { completing work }\end{array}$ & -.130 & -2.413 & .016 & -.184 & -.132 & -.121 & .869 & 1.150 \\
\hline & $\begin{array}{l}\text { Scope of } \\
\text { development }\end{array}$ & -.200 & -3.922 & .000 & -.203 & -.211 & -.197 & .975 & 1.026 \\
\hline & Rationalization & .016 & .309 & .757 & .000 & .017 & .016 & .958 & 1.044 \\
\hline & $\begin{array}{l}\text { Personal } \\
\text { development }\end{array}$ & -.011 & -.205 & .838 & .001 & -.011 & -.010 & .934 & 1.071 \\
\hline 1 & open-ness & .039 & .761 & .447 & .040 & .042 & .038 & .988 & 1.012 \\
\hline & $\begin{array}{l}\text { No-presser } \\
\text { feeling }\end{array}$ & .017 & .338 & .735 & .026 & .019 & .017 & .957 & 1.045 \\
\hline & Freedom & .042 & .824 & .411 & .030 & .045 & .041 & .973 & 1.028 \\
\hline & $\begin{array}{l}\text { Intangible - } \\
\text { returns }\end{array}$ & -.092 & -1.392 & .165 & .037 & -.076 & -.070 & .582 & 1.718 \\
\hline & Tangible returns & .084 & 1.587 & .113 & .124 & .087 & .080 & .902 & 1.108 \\
\hline & Recognition & -.059 & -1.078 & .282 & -.037 & -.059 & -.054 & .855 & 1.169 \\
\hline & Secured future & .115 & 2.105 & .036 & .176 & .115 & .106 & .842 & 1.188 \\
\hline & $\begin{array}{l}\text { Scope of more } \\
\text { earning }\end{array}$ & .079 & 1.527 & .128 & .103 & .084 & .077 & .949 & 1.054 \\
\hline
\end{tabular}




\subsection{Impact of sales force satisfaction on their motivation}

By applying the regression model separately on each motivating factors as dependent variable and all the satisfying factors as independent variables, the results (Table 7) refers that only five individual regression models show the significant (Sig. values $=0.000,0.003,0.001,0.000,0.004)$ impact (values of adjusted $R^{2}=0.181,0.037$, $0.047,0.182,0.035)$ of satisfaction on five motivating factors separately.

Table 7: Regression Statistics

\begin{tabular}{|c|c|c|c|c|c|c|c|c|c|c|}
\hline \multicolumn{6}{|c|}{ Model Summary } & \multicolumn{5}{|c|}{ Model fitting by ANOVA } \\
\hline \multirow{2}{*}{ Model } & \multirow{2}{*}{$\mathrm{R}$} & \multirow{2}{*}{$\begin{array}{c}\mathrm{R} \\
\text { Square }\end{array}$} & \multirow{2}{*}{$\begin{array}{l}\text { Adjusted } \\
\text { R Square }\end{array}$} & \multirow[b]{2}{*}{$\begin{array}{c}\text { Std. } \\
\text { Error of } \\
\text { the } \\
\text { Estimate }\end{array}$} & \multirow{2}{*}{$\begin{array}{c}\text { Change } \\
\text { Statistics } \\
\text { Sig. F } \\
\text { Change }\end{array}$} & \multicolumn{3}{|c|}{ Sum of squires of } & \multirow{2}{*}{$\mathrm{F}$} & \multirow{2}{*}{ Sig. } \\
\hline & & & & & & Regression & Residual & Total & & \\
\hline 1 & 0.439 & 0.193 & 0.181 & 0.902017 & 0.000 & 65.825 & 275.009 & 340.88 & 16.18 & 0.000 \\
\hline 2 & 0.153 & 0.024 & 0.009 & 0.996484 & 0.151 & 8.095 & 335.627 & 343.42 & 1.631 & 0.151 \\
\hline 3 & 0.226 & 0.051 & 0.037 & 0.982589 & 0.003 & 17.625 & 326.333 & 343.95 & 3.651 & 0.003 \\
\hline 4 & 0.163 & 0.027 & 0.012 & 0.994911 & 0.103 & 9.143 & 334.568 & 343.71 & 1.847 & 0.103 \\
\hline 5 & 0.062 & 0.004 & -0.011 & 1.006831 & 0.933 & 1.331 & 342.633 & 343.96 & 0.263 & 0.933 \\
\hline 6 & 0.104 & 0.011 & -0.004 & 1.003137 & 0.595 & 3.714 & 340.124 & 343.83 & 0.738 & 0.595 \\
\hline 7 & 0.247 & 0.061 & 0.047 & 0.977446 & 0.001 & 21.049 & 322.925 & 343.97 & 4.406 & 0.001 \\
\hline 8 & 0.174 & 0.030 & 0.016 & 0.993396 & 0.063 & 10.449 & 333.551 & 343.99 & 2.118 & 0.063 \\
\hline 9 & 0.154 & 0.024 & 0.009 & 0.996723 & 0.147 & 8.189 & 335.788 & \begin{tabular}{|l|}
343.97 \\
\end{tabular} & 1.648 & 0.147 \\
\hline 10 & 0.440 & 0.194 & 0.182 & 0.901238 & 0.000 & 65.978 & 274.534 & 340.51 & 16.24 & 0.000 \\
\hline 11 & 0.221 & 0.049 & 0.035 & 0.983754 & 0.004 & 16.812 & 327.107 & 343.91 & 3.474 & 0.004 \\
\hline 12 & 0.099 & 0.010 & -0.005 & 1.003634 & 0.647 & 3.368 & 34.461 & 343.82 & 0.669 & 0.647 \\
\hline 13 & 0.139 & 0.019 & 0.005 & 0.999022 & 0.249 & 6.655 & 337.339 & 343.99 & 1.334 & 0.249 \\
\hline 14 & 0.131 & 0.017 & 0.003 & 1.000062 & 0.317 & 5.919 & 338.042 & 343.96 & 1.184 & 0.317 \\
\hline
\end{tabular}

Model-1, 2, 3, 4, 5, 6, 7, 8, 9, 10, 11, 12, 13, 14 refers to impact of sales-force satisfaction on belongingness, internal environment, ease of completing the work, scope of development, rationalization, personal development, open-ness, no-presser feeling, freedom, intangible returns, tangible returns, recognition, secured future and on scope of more earning respectively.

For all models, $d f-1$ and $d f-2$ refers to 5 and 338 respectively.

The results of ANOVA show that linear regression model can be applied on these five relationships only, because of the significant (Sig. values $=0.000,0.003$, $0.001,0.000,0.004) \mathrm{F}$ statistics $(16.180,3.651,4.406,16.246,3.474)$. So it is inferred that satisfaction factors have the impact only on five on the motivating factors like belongingness, ease of completing the work, open-ness, intangible returns, and tangible 
returns by $18 \%, 3 \%, 4 \%, 18 \%, 3 \%$ respectively. Very less multicollinearity is observed (Table 8 ) in the above regression modelling, as all the tolerance value are 1.000 (When the tolerances are close to 0 , there is high multicollinearity) and all the VIF values are 1.000 (A variance inflation factor greater than 2 is usually considered problematic) justifying very less multicollinearity, as can be inferred from Table 8 .

Table 8: Coefficients

\begin{tabular}{|c|c|c|c|c|c|c|c|c|c|}
\hline \multirow{2}{*}{\multicolumn{2}{|c|}{ Model }} & \multirow{2}{*}{$\begin{array}{c}\begin{array}{c}\text { Standardized } \\
\text { Coefficients }\end{array} \\
\text { Beta } \\
\end{array}$} & \multirow[t]{2}{*}{$\mathbf{t}$} & \multirow[t]{2}{*}{ Sig. } & \multicolumn{3}{|c|}{ Correlations } & \multicolumn{2}{|c|}{$\begin{array}{c}\text { Collinearity } \\
\text { Statistics }\end{array}$} \\
\hline & & & & & $\begin{array}{l}\text { Zero- } \\
\text { order }\end{array}$ & Partial & Part & Tolerance & VIF \\
\hline \multirow{6}{*}{1} & (Constant) & & -.106 & .915 & & & & & \\
\hline & Career -planning & .419 & 8.574 & .000 & .419 & .423 & .419 & 1.000 & 1.000 \\
\hline & Work- condition & .053 & 1.075 & .283 & .053 & .058 & .053 & 1.000 & 1.000 \\
\hline & Assignment & .036 & .738 & .461 & .036 & .040 & .036 & 1.000 & 1.000 \\
\hline & Relationship & .115 & 2.348 & .019 & .115 & .127 & .115 & 1.000 & 1.000 \\
\hline & Compensation & .021 & .428 & .669 & .021 & .023 & .021 & 1.000 & 1.000 \\
\hline
\end{tabular}

\subsection{Findings and Conclusion}

From the thirty-two motivation variables (indirectly asked items in the questionnaire), nine factors extracted as belongingness, internal environment, ease of completing the work, scope of development, rationalization, personal development, open-ness, no-presser feeling, freedom. Sixteen motivation variables (directly asked items in the questionnaire) lead to five factors that motivate the life-insurance sales force in India. Five factors extracted from fifteen variables that are causing sales-force satisfaction in life insurance industry. These factors are career planning, work condition, assignments, relationships and compensation. Although motivation factors are predicting fewer characteristics (13\% variance) of the performance, this has a great meaning along the satisfaction factors for the performance of the life-insurance sales persons, which can be justified logically by the following points. 
(i) Motivators like 'belongingness' and 'internal environment' have the impact by $22 \%$ and $13 \%$ respectively on performance. Belongingness ultimately predicted five satisfaction factors by $18 \%$, which means 'belongingness' is such a factor that must be given maximum importance by the life-insurance companies. Further, belongingness can create a conducive internal environment of the company.

(ii) The sales-force satisfaction has significant positive impact on motivation factor 'ease of completing the work', which is a significant negative predictor of sales force performance. This means that sales employees' happiness by completing the work easily is not at all desirable for life insurance companies.

(iii) Although, it is surprising that 'scope of development' has significant negative impact on performance, this factor can be used carefully for temporary or local motivation of the sales force. That means this factor should not be linked to the performance directly or for a long time period, because it does not influenced by the satisfaction factors.

(iv) Although 'openness' is not predicting the performance, it has a significant positive influence on sales force satisfaction. So it has the potential to create a pleasant 'internal environment' for the sales people of life insurance companies.

(v) The motivation factor 'secured future' is predicting significantly the sales force performance, but is not influenced by the satisfaction of concerned sales force. So this factor becomes very basic ingredient of organisational life span of the sales people in the life insurance industry.

(vi) The motivating factors 'intangible returns' and 'tangible returns' are influenced by sales force satisfaction, but not predicting the performance. So these motivating factors can be used for situational management and not for the performance. Again it can be interpreted that these two motivating factors can be used for temporary boost for the work itself, not for the result of the work. These two factors can be used for any other purpose rather than performance like local conflict management, employee retention or any such outputs of the organisation that take the mediating role for the performance of the sales force of the life insurance companies in India.

Overall it can be concluded that the satisfaction factors create a unique and complex psychological field (summation of all the thoughts specific to an organisation) that uphold the 'motivation' path for the performance or any other mediating path for the performance of the sales force of the life insurance companies in India. Any mismatch of building blocks in creating that field or any composition error of the psychological field will raise questions against the managerial skills, otherwise this field will be relatively enduring and can perpetuate the performance. 


\subsection{Limitation of the study}

As already mentioned, time and budgetary constraints restricted the sample size to 345 ; it will be more meaningful to take a grater sample size by which statistical inferences can be drawn more strongly. Some other factors like the power in the authority hierarchy, demographic features and influence of geographical areas may moderate the performance, which is not addressed in the current research. These factors can be included to make the results more applicable. The relationship between satisfaction, motivation and performance in a sequence can be studied by the advanced statistical technique like structural equation modeling to get more meaningful ideas. So many other variables of motivation and satisfaction are there, which can be taken to study this issue more minutely.

\section{References}

Anagol, S., Shayak, S. \& Cole, S. (2012). Understanding the advice of agents: Evidence from the Indian Life Insurance Market. Harvard Business School Working paper 12-055.

Balachandar, G., Panchanatham, N., \& Subramanian, K. (2010). Impact of job situation on the motivation of insurance companies officers: A development perspective. International Journal of Trade, Economics and Finance, 1(4), 349-353.

Bishka, A. (1993). A performance-based development system. Nursing Management, 24(6), 32-34.

Chowdhury, M. S. (2008). Enhancing motivation and work performance of the salespeople: The impact of supervisors' behaviour. International Journal of Applied Management and Technology, 6(1), 166-181.

Corr, P. J., \& Gray, J. A. (1996). Attributional style as a personality factor in insurance sales performance in the UK. Journal of Occupational and Organizational Psychology, $69,83-87$.

Hafer, J. \& McCuen, B. A. (1985). Antecedents of performance and satisfaction in a service sales force as compared to an industrial sales force. The Journal of Personal Selling and Sales Management, 5(2), 7-17. 
Leach, M. P., Liu, A. H. \& Johnson, W. J. (2005). The role of self-regulation training in developing the motivation management capabilities of salespeople. Journal of Personal Selling \& Sales Management, 25(3), 269-281.

Mulki, J. P., Jaramillo J. F. \& Locander, W. B. (2006). Effects of ethical climate and supervisory trust on salesperson's job attitudes and intentions to quit. Journal of Personal Selling and Sales Management, 26(1), 20-26.

Nohria, N., Groysberg, B., Lee, L., Nohria, N., Groysberg, B., Lee, L., \& Freud, S. (2008). Employee motivation: A powerful new model. Harvard Business Review, 86(78), 78-84.

Pathak, S., \& Tripathi, V. (2010). Sales force turnover: An exploratory study of the Indian insurance sector. Directory of Open Access Journal, 5, 3-19.

San, O. T., Theen, Y. M., \& Heng, T. B. (2012). The reward strategy and performance measurement (Evidence from Malaysian insurance companies). International Journal of Business, Humanities and Technology, 2(1), 211-223.

Tsai, W. C., Chen, C. C. \& Liu, H. L. (2007). Test of a model linking employee positive moods and task performance. Journal of Applied Psychology, 92(6), 1570-1583.

Verma, R., \& Aggarwal, A. (2012). A study of attrition rate among sales force of life insurance companies in Delhi. International Refereed Research Journal, 3(4), 90-99. 